\begin{tabular}{c}
\hline \\
ACPES Journal of Physical Education, Sport, and Health 1 (1) (2021) \\
ACPES Journal \\
http://journal.unnes.ac.id/sju/index.php/ajpesh \\
\hline
\end{tabular}

\title{
The Effect of Movement Control Order on Quality of Life among Staffs in Faculty of Sport Science and Recreation UiTM Shah Alam
}

\author{
Mohammad Alif Ismail ${ }^{\bowtie}$, Ahmad Fadhil Nazeri, Nur Ain Iwani Zailan, Noor Fatihah \\ Ilias
}

Faculty of Sport Science and Recreation, UiTM Shah Alam, Malaysia

DOI: https://doi.org/10.15294/ajpesh.v1i1.46296

\begin{tabular}{l} 
Article Info \\
\hline Article History \\
Submitted 9 January 2021 \\
Revised 28 April 2021 \\
Accepted 14 June 2021 \\
\hline
\end{tabular}

Keywords

Movement Control Order; Quality of Life; Academic Staff, Administrative Staff

\begin{abstract}
Coronavirus known as COVID-19 is a respiratory illness that affects people worldwide. Malaysia was also affected by this virus; therefore, the government announced the Movement Control Order (MCO) to break the COVID-19 chain. MCO possibly affects quality of life of working people. Therefore, the purpose of this study is to compare the effect of MCO on quality of life between academic and administrative staff in Faculty of Sport Science and Recreation, UiTM Shah Alam. This study utilised causal - comparative research design involved academic and administrative staff. The sample analysed were $\mathrm{N}=52$ comprised of 30 academic and 22 administrative staff. This study used SF-36 questionnaire to measure quality of life. Data was collected via online. T-test was used to identify the differences between the two groups. Academic staff quality of score was $(M=56.90 \pm 6.97)$ and administrative staff was $(M=59.7 \pm 7.54)$ score. The findings reported that there is no significant difference in quality of life, $p=0.669$ between academic and administrative staff during MCO. Quality of life for both academic and administrative staff was affected during MCO due to COVID-19 pandemic.
\end{abstract}

\section{INTRODUCTION}

The coronavirus disease outbreak of 2019 (COVID-19) was identified as severe acute respiratory syndrome coronavirus 2 (SARS-Cov-2), which emerged in Wuhan City, China, and spread worldwide by the end of December 2019 (Zhu et al., 2020). The manifestation of COVID-19 seemed to be coldness, bone pain, fever, respiratory issues, and some diseases like Middle East Respiratory Syndrome (MERS-Cov)

\footnotetext{
$\square$ Correspondence Author:

40450 Shah Alam, Selangor, Malaysia

e-ISSN 2797-0426

E-mail: jitralif.420@gmail.com
} 
(Singhal, 2020). This disease begins to escalate with an increment in the number of cases reported regularly. Last update on February 25, 2021 COVID-19 disease spread to the peak globally with a cumulative number of $113,144,793$ confirmed cases, 2,509,899 deaths and 88,763,031 recovered cases (World Health Organization, 2021).

First case on covid-19 in Malaysia was reported on 25 January 2020, involving three Chinese citizens who had previously had close contact with infected people in Singapore (New Straits Times, 2020 Mar 16). First Malaysian cases was clarified with COVID-19 on 4 February 2020 which is 41 -year-old man had recently returned from Singapore, showing positive sign such as a fever and cough (Elengoe, 2020). In the same month, the incidence rates of COVID-19 increased relatively slowly until a religious event occurred in Sri Petaling, Kuala Lumpur, which triggered an exponential increase in the case (Barker A, 2020).

The number of cases has increased dramatically, and Malaysian governments apparently decided to implement quarantine or isolation of the individual to decrease the number of people affected. Prime Minister Tan Sri Muhyiddin Yassin has decided to launch the first phase of the Movement Controlled Order (MCO) from March 18 to March 31, 2020, that would take two weeks in each phase to break the COVID-19 chain (Ashley, 2020). A series of MCO was implemented to reduce the spreading of the virus. There are few restrictions was applied during the MCO. Part of the restrictions imposed by the government was people were prohibited from attending mass gatherings in sport and recreation events, closure of kindergartens, school, and universities (Fan \& Cheong, 2020).

These restrictions are rapidly shifting to new norms that are appropriate for individuals and society to survive their daily lives during the covid-19 pandemic. Quarantine or self - isolation probably is the best alternative to prevent quick spread of infections, but it may also have implications on health issues. COVID-19 harms people's quality of life, including psychological health, such as stress, despair, depression, and anxiety (Elengoe, 2020; Khanal et al., 2020). According to Jiménez-Pavón et al. (2020), self-isolation seems to have a negative effect on psychological health. Poor psychological health lead to poor quality of life (Carlson et al., 2003). Since the MCO has been applied to break the COVID-19 string, it might have affected psychological health and positively affected people's quality of life.

While during self-isolation, people who might have decided to stay at home to prevent the outbreak of COVID-19 could result in a reduction of regular exercise (Chen et al., 2020). MCO possibility lead to raise sedentary lifestyle behaviors and poor physical activity, poor quality of life and may indeed cause chronic disease (Bas et al., 2020; Roschel et al., 2020). In addition, unhealthy lifestyles are one of the world's leading changeable cardiovascular risk factors and all death rates (Lavie et al., 2019). As reported by Bize et al. (2007), there is a significant correlation between level of physical activity and the quality of life, in which lack of exercise results towards a poor quality of life. Other report by Lippi et al. (2020) MCO has disrupted physical exercise and it has led to prolonged inactivity, that can result in changes in physical body and finally effect on quality of life. Since isolation at home has been implemented to prevent the covid-19 virus chain, sedentary lifestyles could have been triggered and the quality of life of people could have been significantly affected.

University staff possibly affected since the restriction was announced where 
university staff need to adapt e-learning and e-working from home in shorter time. This is because, the government take initiatives to avoid the virus spread in workplace. University staffs were asked to work from home (Sahu, 2020). According to Coman et al. (2020) most of the staff are currently struggling to work from home where it is difficult to completed their work. According to D'Angelus (2020) staff may struggle due to lack of facilities to manage their work from home. In addition, some staff are unable to fulfil in use of information technology (IT) due to lack of skills and information flow to provide an online class to students (Onyema et al., 2020). This could lead to poor work quality, indirectly affect quality of life. Since transmission at home was being put throughout sufficient to prevent the COVID-19 string, quality of life among staff might have been affected.

Quality of life response to the Covid-19 outbreak remains unknown. Self-isolation linked with COVID-19 has a possible effect on quality-of-life staff. Limited studies have investigated the severe impact of strict quarantine on quality of life (Zhang $\& \mathrm{Ma}, 2020)$. Therefore, the aims of this study are to identify the effect of MCO on quality of life between academic and administrative staff of FSR Shah Alam.

\section{METHOD}

\section{Study Population}

Purposive sampling approach was applied to recruit the respondents. Based on record from faculty registrar's office, the total sample consisted of 44 academic and 24 administrative staff in the Faculty of Sport Science and Recreation. Based on Krejcie Morgan's table, 40 academic staff $(n=40)$ and 24 administrative staff $(n=24)$, were recruited. The final staff participating in this study were $30(68.2 \%)$ academic staff and 22 (91.6\%) administrative staff participated in this study. This research was approved by the UiTM ethic committee: (REC/1/19). All the participants are free to participate, and they were informed regarding the methodology and benefit of the research.

\section{Data Collection Procedure}

SF-36 questionnaire was used to evaluate the quality of life. Data was collected using Google form via WhatsApp and e-mail. Data was collected after obtaining UiTM Ethics Approval. Questionnaires were given to the participants who were randomly selected.

\section{Instrumentation}

The SF-36 by RAND Corporation was used to identify the quality of life for this study. The SF-36 questionnaire is one of the most extensively used and tested instruments worldwide (Sararaks et al., 2005). The SF-36 is reported to be a sensitive measure to changes in health in general populations (Hemingway et al., 1997). It is easy to use, acceptable to patients, and fulfils stringent criteria of reliability and validity (Brazier et al., 1992). The SF-36 consisted of 36 multiple-choice questions measuring 8 distinct domains which are physical functioning, role limitations due to physical health, role limitation due to emotional problem, energy/fatigue, emotional well-being, social functioning, bodily pain, and general health perception. Scores are coded, summed and converted to produce a score from 0 (worst possible state of 
health) to 100 (Burckhardt \& Anderson, 2003). The items in the same scale were averaged together. For a final score, all the eight topics were totaled up. Higher score is considered as good health-related quality of life. According to the Burckhardt and Anderson (2003) score more than 90 is thought to be a good quality of life, while a score of less than 90 is assumed to have a poor quality of life.

\section{Statistical analysis}

Data were analyzed using Statistical Package for Social Sciences (SPSS 2.0). Descriptive analysis used to describe the study demographic data. The independent t-test was used to compare the quality-of-life between academic and administrative staff in Faculty of Sport Science and Recreation UiTM Shah Alam. The value of $p<$ .05 was considered significant.

\section{RESULT AND DISCUSION}

Table 1 presents the respondents characteristics. Overall, 52 staff completed the survey. A total of 30 respondents were academic staff and 22 were administrative staff from the Faculty of Sport Science and Recreation, UiTM Shah Alam.

Table 2 showed there is no significant different in quality-of-life mean score between academic $(M=56.90, \pm 6.97)$ and administrative staff $(M=59.70 \pm 7.54), t$ $(50)=-1.37, p>.176$. The mean difference for quality-of-life score between academic and administrative staff is 2.8 .

This study managed to show the quality of life for the staff in the Faculty of Sport Science and Recreation, UiTM Shah Alam during the MCO due to COVID-19 outbreak. Restriction or quarantine due to covid-19 pandemic had made an impact on staff quality of life. Based on this result, all academic and administrative staff suffered a poor quality of life during the COVID-19 outbreak. Both groups indicated low score in quality of life.

The possible factor that could lead to poor quality of life among staff during the covid-19 pandemic was new work demand as staff were to follow new working norms which was working online from home. According to Fayomi et al. (2015), e-learning causes an increase in the number of work among staff at universities. A lot of work needs to be done at home, with limited facilities such as internet coverage and laptops. This finding supported that staff were experiencing lack of facility to perform their task at home (D'Angelus, 2020). Due to this limitation, the quality of work is possibly affected. In addition, working from home was very challenging (Hosna et al., 2020). According to Dziuban et al. (2018) new norm in the education sector has triggered lower quality of life. Possibly, increased job demand, scarcity of facilities, and unfamiliarity with the new way of working may have led to the staff's poor quality of life during the covid-19 pandemic.

Table 1. Characteristic of the respondents

\begin{tabular}{lll}
\hline Variables & $f(\%)$ & Mean (SD) \\
\hline Department & & \\
Academic staff & $30(57.7)-$ \\
Administrative staff & $22(42.3)-$
\end{tabular}


Age

$18-24$

25-34

$35-44$

45-54

$21(40.4)-$

$55-70$

$6(11.6) \quad-$

Health-related Quality of Life Category

Academic staff

$56.90(6.97)$

Administrative staff

$59.70(7.54)$

Table 2. Comparison Quality of Life between Academic and Administrative staff

\begin{tabular}{llllll}
\hline & $\mathrm{n}$ & Mean (SD) & $\mathrm{t}$ & $\mathrm{df}$ & $p$ value \\
\hline Health-related Quality of Life & 30 & $56.90(6.97)$ & -1.37 & 50 & .176 \\
& 22 & $59.70(7.54)$ & & & \\
\hline
\end{tabular}

Besides, since all staff need to self - isolate and start working from home, most staff could reduce their physical activity level, changing to sedentary behaviors. According to Bas et al. (2020), COVID-19 impacted the people with lack of exercise, longer screen time, irregular sleeping habits, and also excess body weight. Roschel et al. (2020), further explained that possibilities of staff to lead sedentary lifestyle was high and possibly reduce quality of life level during covid-19 pandemic. Restriction from going to gymnasiums, recreational parks and sport centers were implemented, which changes public habit to exercise. Inability to design exercise at home and not inability to adapt with the new norm could be the contributing factors. Consequently, lack of physical activity or a sedentary lifestyle can result to a low physical wellbeing, which lead to decrease quality of life.

The other possible factor that leads to poor quality of life among staff is lack of time to manage office jobs and family issues. Working from home for some of the staff were not easy as they need to take care of the little children as well performing their job at the same time. Both responsibilities required focus and can be demanding which indirectly lead to overwork (Cluver et al., 2020; Vyas \& Butakhieo, 2021). According to Ezpeleta et al. (2020) new norms and restriction have resulted with mental health issues among family members. This could lead to poor job quality and stress among staff. COVID -19 pandemic and movement control order affect physical, mental, social and activities which impacted the quality of life of the staff.

Poor quality of life among staff possibly due to the limitation of skill in using new methods of working which is e-learning and e-working. Majority of these respondents were over 35-year-olds, and they were mostly from $\mathrm{X}$ generation. This generation preferred teaching and working approaches that uses pen and paper because they have so used to it. Extra effort is required to adapt with the transition from current teaching and working approaches (Bejtkovský, 2016). Possibly, staff are not familiar with the new method of teaching or working that could lead to poor quality of life. They need to spend extra time to adapt with the new era of learning and working using laptops, phones, and online meetings.

Results of this study showed there is no significant difference in quality of life 
seen between academic and administrative staff during the COVID-19 pandemic. During the $\mathrm{MCO}$, lecturers were unable to interact with their students face to face, causing them to lose motivation and trust (Hashim et al., 2020). Furthermore, several academic staff who work from home are feeling difficult to perform their task and having difficulty with online teaching and learning (Diab-Bahman \& Al-Enzi, 2020). Besides, several academic staff will also suffer with digital challenges in delivering knowledge to students, such as a lack of technology, expertise, or communication (Onyema et al., 2020). Academic staff may suffer stress because of increased workload, which includes teaching, preparing and performing other responsibilities during online sessions (Rapanta et al., 2020). Moreover, academic staff may face several challenges due to lack of pedagogical knowledge about teaching online (Rapanta et al., 2020). Cancellation of face-to-face class required academic staff to do extra job to re-design the teaching method to ensure the class run smoothly. Academic staff may need more time to be familiar with the new method of teaching. This circumstances possibly lead to stress and indirectly caused poor quality of life.

Administrative staff also experience poor quality of life possibly due to increase in work demand. New norms have pushed administrative staff to re-think, re-design, and think outside the box to make the best option for the organization's smooth operation. According to Carnevale and Hatak (2020), to restrict people contact, administrative staff must re-create new and current employee job arrangements, work shifts, policies, and procedures. Besides, administrative staff have been forced to adapt with the new approaches of working to achieve organizational objectives (Carnevale \& Hatak, 2020). Furthermore, working from home results in a reduction in productivity since they also need to focus on their families, resulting in overwork (Vyas \& Butakhieo, 2021). As a result, the new norms have caused administrative staff to work hard, rethink, redesign, and create a new platform as new norms which led them to stress and tension, also lead to poor quality of life.

Good quality of life is essential for maintaining employee performance and productivity to achieve the organization's goals (Mamaghaniyeh et al., 2019). Therefore, the organization must consider quality of life as an important factor to produce good work performance among staff, and lead to achieve organization goals. More research is needed to determine quality of life among other faculty members and across other campuses. Academic staff's technology skill must be improved with recent approaches in learning are focused on online approaches. Academic staff expertise combined with cutting-edge technology will result in learning advances aid students in better learning process. Administrative staff should adapt to the new norm in a shorter amount of time to ensure that the supporting infrastructure is well-organized, and that the university's goal can be met. This puts the educational sectors into the $21^{\text {st }}$ century's new world era.

\section{CONCLUSION}

Finally, staff were valuable sources for the future development of the education industry. Academic and administrative staffs also contribute to an organization's success relate with 21st-century priorities. However, COVID-19 is starting to have an impact in education field, especially among academic and administrative personnel. As a result, they may engage with sedentary behavior, experience mental health is- 
sues, and have a lower quality of life. During the COVID-19 pandemic, staff should improve good health, alleviate stress, and improve their quality of life. Academic and administrative staff must encourage themselves to adapt with the new approaches of working. Staffs must be involved in physical activity to minimize stress levels to preserve healthy health. Poor quality of life, it could influence work quality and may retard the achievement of organizational goal. Generally, university staff are the ones that need special attention because they are important in creating and achieving the organization's long-term objectives. Small number of respondents in this study is one of the limitations in this study. More studies related to the impact of Covid-19 pandemic among employees, with larger sample size are needed.

\section{REFERENCES}

Ashley, T. 2020. Malaysia Announces Movement Control Order after Spike in COVID-19 Cases (updated). The Star Online. 16 March. https://www.thestar.com.my/news/nation/2020/03/16/malaysia-announces-restricted-movement-measure-after-spike-in-covid-19-cases

Barker A. 2020. Coronavirus COVID-19 Cases Spiked Across Asia after a Mass Gathering in Malaysia. This is How it Caught the Countries by Surprise. ABC News. Mar 19. Available from: https:// www.abc.net.au/news/2020-03-19/coronavirus-spread-from-malaysian-event-tomultiple-countries/12066092

Bas, D., Martin, M., Pollack, C., \& Venne, R. 2020. The Impact of COVID-19 on Sport, Physical Activity and Well-being and its Effects on Social Development. New York: UN. Department of Economics and Social Affairs.

Bejtkovský, J. 2016. The Employees of Baby Boomers Generation, Generation X, Generation Y and Generation $\mathrm{Z}$ in Selected Czech Corporations as Conceivers of Development and Competitiveness in their Corporation. Journal of Competitiveness, 8(4): 105-123.

Bize, R., Johnson, J. A., \& Plotnikoff, R. C. 2007. Physical Activity Level and Health-related Quality of Life in the General Adult Population: A Systematic Review. Preventive Medicine, 45(6): 401-415.

Brazier, J. E., Harper, R., Jones, N., O'cathain, A., Thomas, K., Usherwood, T., \& Westlake, L. 1992. Validating the SF-36 Health Survey Questionnaire: New Outcome Measure for Primary Care. British Medical Journal, 305(6846): 160-164.

Burckhardt, C. S., \& Anderson, K. L. 2003. The Quality of Life Scale (QOLS): Reliability, Validity, and Utilization. Health and Quality of Life Outcomes, 1(1): 1-7.

Carlson, L. E., Speca, M., Patel, K. D., \& Goodey, E. 2003. Mindfulness-based Stress Reduction in Relation to Quality of Life, Mood, Symptoms of Stress, and Immune Parameters in Breast and Prostate Cancer Outpatients. Psychosomatic Medicine, 65(4): 571-581.

Carnevale, J. B., \& Hatak, I. 2020. Employee Adjustment and Well-being in The Era of COVID-19: Implications for Human Resource Management. Journal of Business Research, 116: 183-187.

Chen, P., Mao, L., Nassis, G. P., Harmer, P., Ainsworth, B. E., \& Li, F. 2020. Wuhan Coronavirus (2019nCoV): The Need to Maintain Regular Physical Activity while Taking Precautions. Journal of Sport and Health Science, 9(2): 103.

Cluver, L., Lachman, J. M., Sherr, L., Wessels, I., Krug, E., Rakotomalala, S., Blight, S., Hillis, S., Bachman, G., \& Green, O. (2020). Parenting in aTime of COVID-19. Lancet, 395(10231).

Coman, C., Țîru, L. G., Meseșan-Schmitz, L., Stanciu, C., \& Bularca, M. C. 2020. Online Teaching and Learning in Higher Education during the Coronavirus Pandemic: Students' Perspective. Sustainability, 12(24): 10367.

D’Angelus, M. M. 2020. Malaysia - Employers' Obligations During Movement Control Order (MCO). 13 April. Available from: https://www.conventuslaw.com/report/malaysia-employers-obligations-duringmovement/

Diab-Bahman, R., \& Al-Enzi, A. 2020. The Impact of COVID-19 Pandemic on Conventional Work Settings. International Journal of Sociology and Social Policy. 40(9): 909-927.

Dziuban, C., Graham, C. R., Moskal, P. D., Norberg, A., \& Sicilia, N. 2018. Blended Learning: the New Normal and Emerging Technologies. International Journal of Educational Technology in Higher Education, 15(1): 1-16.

Elengoe, A. 2020. COVID-19 Outbreak in Malaysia. Osong Public Health and Research Perspectives, 11(3): 93. Ezpeleta, L., Navarro, J. B., de la Osa, N., Trepat, E., \& Penelo, E. 2020. Life Conditions during COVID-19 
Lockdown and Mental Health in Spanish Adolescents. International Journal of Environmental Research and Public Health, 17(19): 7327.

Fan, V. \& Cheong, R. 2020. MCO, CMCO, RMCO, CMCO Again: Regulations and SOPs. 6 November. Available from: https://mahwengkwai.com/mco-cmco-rmco-regulations-sops/

Fayomi, O. O., Ayo, C., Ajayi, L. A., \& Okorie, U. E. 2015. The Impacts of e-learning in Facilitating Academic Performance among Private Secondary Schools and Tertiary Institutions in Ota, Ogun State, Nigeria. Presented in $9^{\text {th }}$ International Technology, Education and Development Conference, Madrid, Spain, 2-4 March 2015.

Hashim, H., Kadir, N. A. A., Mansor, F., \& Azudin, M. Z. M. 2020. Open and Distance Learning (ODL) During Movement Control Order (MCO): Conceptualising the Relationships between Self-Efficacy, Learning Motivation and Performance of Higher Learning Education Students. International Journal of Academic Research in Business and Social Sciences, 10(8): 258-269.

Hemingway, H., Stafford, M., Stansfeld, S., Shipley, M., \& Marmot, M. 1997. Is the SF-36 a Valid Measure of Change in Population Health? Results from the Whitehall II study. British Medical Journal, 315(7118): 1273-1279.

Hosna, A. U., Wahab, S. A., Hamid, M., Hasanat, M. W., Haque, A., Anum, K., \& Kamruzzaman, M. 2020. Impact of Mental Pressure and Coronavirus (Covid-19) on the Work Performance of Working Mothers of Bangladesh. American International Journal of Business Management, 3(12): 63-69.

Jiménez-Pavón, D., Carbonell-Baeza, A., \& Lavie, C. J. 2020. Physical Exercise as Therapy to Fight against the Mental and Physical Consequences of COVID-19 Quarantine: Special Focus in Older People. Progress in Cardiovascular Diseases, 63(3): 386.

Khanal, P., Devkota, N., Dahal, M., Paudel, K., \& Joshi, D. 2020. Mental Health Impacts among Health Workers During COVID-19 in a Low Resource Setting: A Cross-sectional Survey from Nepal. Globalization and Health, 16(1): 1-12.

Lavie, C. J., Ozemek, C., Carbone, S., Katzmarzyk, P. T., \& Blair, S. N. 2019. Sedentary Behavior, Exercise, and Cardiovascular Health. Circulation Research, 124(5): 799-815.

Lippi, G., Henry, B. M., \& Sanchis-Gomar, F. 2020. Physical Inactivity and Cardiovascular Disease at the Time of Coronavirus Disease 2019 (COVID-19). European Journal of Preventive Cardiology, 27(9): 906-908.

Mamaghaniyeh, M., Sadeghi, M., \& Amani, S. 2019. The Quality of Working Life among Employees. International Journal of Human Capital in Urban Management, 4(3): 213-222.

New Straits Times. 2020. Covid-19: Movement Control Order Imposed with Only Essential Sectors Operating. Mar 16. New Straits Times. Available from: https://www.nst.com.my/news/nation/2020/03/575177/covid-19-movement-control-order-imposed-only-essential-sectors-operating.

Onyema, E. M., Eucheria, N. C., Obafemi, F. A., Sen, S., Atonye, F. G., Sharma, A., \& Alsayed, A. O. 2020. Impact of Coronavirus Pandemic on Education. Journal of Education and Practice, 11(13): 108121.

Rapanta, C., Botturi, L., Goodyear, P., Guàrdia, L., \& Koole, M. 2020. Online University Teaching During and After the Covid-19 Crisis: Refocusing Teacher Presence and Learning Activity. Postdigital Science and Education, 2(3): 923-945.

Sahu, P. 2020. Closure of Universities Due to Coronavirus Disease 2019 (COVID-19): Impact on Education and Mental Health of Students and Academic staff. Cureus, 12(4).

Sararaks, S., Azman, A., Low, L., Rugayah, B., Aziah, A., Hooi, L., Razak, M. A., Norhaya, M., Lim, K., \& Azian, A. 2005. Validity and Reliability of the SF-36: The Malaysian Context. Medical Journal of Malaysia, 60(2): 163.

Singhal, T. 2020. A Review of Coronavirus Disease-2019 (COVID-19). The Indian Journal of Pediatrics, 87(4), 281-286.

Vyas, L., \& Butakhieo, N. 2021. The Impact of Working from Home during COVID-19 on Work and Life Domains: An Exploratory Study on Hong Kong. Policy Design and Practice, 4(1): 59-76.

World Health Organization. 2021. WHO Coronavirus Disease (COVID-19) Dashboard. https://covid19.who. int/.

Zhang, Y., \& Ma, Z. F. (2020). Impact of the COVID-19 Pandemic on Mental Health and Quality of Life among Local Residents in Liaoning Province, China: A Cross-sectional Study. International Journal of Environmental Research and Public Health, 17(7): 2381.

Zhu, N., Zhang, D., Wang, W., Li, X., Yang, B., Song, J., Zhao, X., Huang, B., Shi, W., \& Lu, R. 2020. A Novel Coronavirus from Patients with Pneumonia in China, 2019. New England Journal of Medicine, 382: 727-733. 